\title{
PERAN INTERNAL AUDITOR DALAM PENCEGAHAN \\ KECURANGAN PENGELOLAHAN DANA DESA \\ (Studi Kasus Pada Inspektorat Kabupaten Bengkulu Selatan)
}

\author{
Hernadianto $^{1}$, Nour Ardiansyah Hernadi ${ }^{2}$, Muhamad Redho Herzianto ${ }^{3}$ \\ ${ }^{1,3}$ Fakultas Ekonomi dan Bisnis, Universitas Muhammadiyah Bengkulu \\ ${ }^{2}$ STIPRAM Yogyakarta \\ Email : hernadianto@umb.ac.id, ardiansyahq@gmail.com, \\ muhamadredho8@gmail.com
}

\begin{abstract}
ABSTRAK
Penelitian ini bertujuan untuk menguji pengaruh variabel: Peran internal auditor terhadap pencegahan kecurangan(fraud) pengelolaan keuangan dana desa. Penelitian ini menggunakan metode survey dengan kuesioner, jumlah Popuasi dalam Peneitian ini adalah 20 orang auditor inspektorat kabupaten Bengkulu selatan yang melakukan audit dana desa di Kabupaten Bengkulu Selatan dan sekaligus di gunakan semua sebagai Sampel Penelitian. Analisis data menggunakan regresi linier sederhana. Hasil penelitian menunjukkan bahwa peran internal auditor berpengaruh signifikan terhadap pencegahan kecurangan (fraud) pengelolaan keuangan dana desa. Hal tersebut dapat dilihat berdasarkan hasil uji regresi sederhana yaitu uji t. Pada Uji t di peroleh hasil nilai signifikan( $\operatorname{sig~} \mathrm{a}=0.005)=<\alpha 0,5(\mathrm{H} 1$ diterima).jadi peran internal auditor yaitu berpengaruh positif dan signifikan terahadap pencegahan kecurangan pengelolahan dana desa.
\end{abstract}

Kata kunci: peran internal auditor dalam pencegahan kecurangan.

ABSTRACT

This study aims to test the effect of the internal auditors ' role variables on the prevention of fraud of village fund management. This study used the survey method with questionnaire. The number of samples used is 20 Inspectorate auditors in South Bengkulu Regency who conduct the audit of village funds in South Bengkulu Regency. Data analysis uses simple linear regression. The results showed that the internal auditor's role was significant to the prevention of fraud of village funds management, it can be seen based on the results of a simple regression test, i.e. $t$-test. On the t-test, it was obtained significant value results $($ sig $\mathrm{a}=0.005)=<\alpha 0,5$ (H1 is accepted).

Keywords: The role of internal auditor in fraud prevention.

\section{PENDAHULUAN}

Undang-Undang Nomor 6 Tahun 2014 tentang Desa, memberikan perubahan secara signifikan dalam tata kelola pemerintahan desa. UU Nomor 6 tahun 2014 juga memberikan hak terhadap desa untuk mendapatkan pengalokasian dana desa dan mengelolah dana tersebut. Pengalokasian dana desa tersebut diharapkan desa dapat termotivasi untuk menjadi lebih mandiri dan kredibel serta dapat memenuhi kebutuahannya sendiri dengan membuat insfrastruktur 
penunjang ekonomi dan badan usah yang berorientasi terhadap kesejahtraan masyarakat desa. Dan tidak semata begantung terhadap pemerintah daerah maupun pusat. Dana Desa berasal dari alokasi Angagaran Pendapatan dan Belanja Negara (APBN) yang diperuntukan kepada desa dengan anggaran yang yang cukup besar, sehingga menjadi perhatian bagi semua pihak. Dalam pengelolahan keuangan desa tersebut perlu diperhatikan dan ditaati asas umum pengelolahan keuangan desa yaitu, keuangan desa harus dikelolah secara tertib, taat pada peraturan perundangundangan, transparan, akuntabel, dan partisipasif dengan memperhatikan asas keadilan, kepatuhan dan manfaat bagi masyarakat desa.

Namun dilain hal sering kali terjadi problem dalam pengelolahan dana, seperti kecurangan dan kesalahan dalam merealisasikan dana desa, hal tersebut terjadi karena adanya kesempatan dari perangkat desa sebagai pihak yang mengelolah dana desa untuk melakukan kecurangan. Selain itu kurangnya pemahaman perangkat desa terhadap pengelolahan dana desa itu sendiri menjadi salah satu faktor yang menyebabkan kecurangan dalam pengelolahan dana desa. Dalam tiga tahun terakhir ini khususnya di kabupaten Bengkulu selatan sudah banyak terjadinya kecurangan dalam pengelolahan dana desa. Hal tersebut sangat merugikan dan menyita perhatian dari banyak pihak, baik itu dari pihak pemerintah maupun dari pihak masyarakat umum. Kecurangan atau penyalagunaan dana desa ini tentu sangat berimbas terhadap kegagalan dalam strategi pembangunan yang telah dibuat dan direncanakan oleh pemerintah, ditambah lagi kerugian Negarah yang disebabkan oleh kecurangan pengelolahan dana desa tersebut kurang lebih pasti berpengaruh terhadap keuangan Negara.

Salah satu contoh kasus korupsi dana desa yang terjadi di kabupaten Bengkulu selatan yaitu Kejaksaan Negeri Bengkulu Selatan, resmi menahan Kepala Desa dan Bendahara Desa Gunung Kayo kecamatan Bunga Mas pada Senin (27/1) pagi. Lantaran diduga melakukan korupsi Dana Desa tahun 2016. Marjek Ravelo, S.H, M.H Kasi Pidsus Kejari Bengkulu Selatan mengatakan setelah melakukan pemeriksaan terhadap Kades Gunung Kayo dan Bendaharanya masing-masing berinisial A-I dan W-O secara tertutup selama 2 jam. Keduanya pun langsung ditetapkan sebagai tersangka."Sementara keduanya sudah di tetapkan tersangka dana desa tahun 2016 dan langsung di tahan di titip sementara di rumah tahanan Bengkulu Selatan. Di sisi lain masih menjadi tanda tanya besar tentang seperti apa peran inspektorat daerah sebagai inernal auditor pemerintah yang menangani langsung terhadap pengelolahan Dana Desa, dalam hal pencegahan kecurangan pengelolahan Dana Desa. Inspektorat kabupaten merupakan lembaga pengawasan mengawasi secara langsung pengelolahan dana desa. Kecurangan memang tidak dapat dihilangkan, tapi setidaknya kecurangan dapat diminimalisir. Salah satunya dengan upanya penyuluhan kepada perangkat desa sebagai lembaga yang mengelolah Dana Desa, tentang tata kelolah dana desa dan proses pelaporan hasil pengelolah dana desa kepada internal auditor sebagai lembaga yang memeriksa serta yang memberikan penilaian terhadap penglolahan Dana Desa.

Adapun hubungan inspektorat dengan dana desa diatur dalam surat Kementerian Dalam Negeri No 700/1281/A.1/19 yang di tujukan kepada Gubernur Provinsi, Bupati, Wali Kota Seluruh Indonesia Tentang Pedoman Pengawasan Dana Desa, yang berlandaskan Undang Undang Nomor 6 Tahun 2014 pasal 112 dan pasal 113 dan peraturan menteri dalam negeri nomor 71 tahun 2015 tentang kebijakan pengawasan di lingkungan kementerian dalam negeri dan penyelenggaraan pemerintah daerah tahun 2016 ditegaaskan bahwa salah satu kegiatan Pengawasan Aparat Pengawas Intern Pemerintah (APIP) adalah melakukan pengawasan dana desa, yang dimaksut Aparat Pengawas Intern Pemerintah (APIP) adalah inspektorat provinsi dan inspektorat kabupaten/kota. 
Ditinjau juga dari Pasal 2 dan 3 Peraturan Menteri Dalam Negeri Nomor 7 Tahun 2008 tentang Pedoman dan Tata Cara Pengawasan Atas Penyelenggaraan Pemerintahan Desa, yang menyatakan bahwa pengawasan atas penyelenggaraan pemerintahan desa meliputi administrasi pemerintahan desa yang salah satunya dilakukan terhadap keuangan desa (meliputi dana desa) dimana pengawasan tersebut dilakukan oleh Pejabat Pengawas Pemerintah pada Inspektorat Kabupaten/Kota.

Melihat keadaan pengelolahan terhadap Dana Desa dalam tiga tahun terakhir ini masih banyak terjadinya kasus kecurangan-kecurangan yang dilakukan oleh perangkat desa. Maka perlu adanya suatu tindakan pencegahan terjadinya korupsi, maka kinerja aparatur desa menjadi perhatian yang harus dibenahi, salah satunya melalui sistem penyuluhan yang dilakukan internal auditor untuk pencegahan kecurangan Dana Desa. Alasan peneliti memilih inspektorat kabupaten Bengkulu Selatan sebagai objek penelitian karena insfektorat dipandang sebagai sebuah instansi pengawasan internal yang bersentuhan langsung dengan proses pengelolahan dana desa, dan yang melakukan pemeriksaan, pengawasan dan pembinaan dalam pengelolahan Dana Desa. Inspektorat hendaknya menitikberatkan agenda pemberantasan korupsi Dana Desa pada unsur pencegahan.

Dari uraian diatas peneliti mengambil topik penelitian yang berjudul "Peran Internal Auditor Dalam Pencegahan Kecurangan Pengelolahan Dana Desa" (studi kasus pada inspektorat kabupaten Bengkulu selatan)adalah untuk mengetahui dan mengukur sebatas mana peran internal auditordalam pencegahan kecurangan dalam pengelolahan Dana Desa yang ada dikabupaten Bengkulu selatan.

\section{TINJAUAN LITERATUR}

Auditing Menurut Hernadianto Tasin (2019) adalah proses yang sistematis untuk memperoleh dan mengevaluasi bukti-bukti secara objektif pernyataan mengenai kegiatan dan kejadian-kejadian ekonomi (dengan tujuan) untuk menetapkan tingkat kesesuaian (antara peryataanpernyataan tersebut) dengan kriteria yang telah ditetapkan atau atura-aturan perusahan serta penyampaian hasilnya kepada pemakai yang berkepentingan. Dan serta menurut William F. Massier, Steven M. Glover, dan Douglas F. Prawitt dalam buku Auditing and Assurance services: a systematic approach $8^{\text {th }}$ ed.yang diterjemakan oleh Denies Priantinah, dan Linda Kusumanining Wadari(2014) dalam buku Jasa Audit dan Asuransi,Auditing adalah suatu proses yang sistemmatis untuk memperoleh dan mengvaluasi bukti-bukti secara objektif, pernyataan mengenai kegiatan dan kejadian-kejadian ekonomi dengan tujuan ununtuk menentukan tingkat kesesuaian antara permyataan tersebut dengan krekteria yang telah ditetapkan kebijakan-kebijakan/aturan-aturan perusahaan serta penyampaian hasil kepada pemakai yang berkepentingan. Sejumlah frasa dalam defenisi tersebut harus diperhatikan. Frasa "proses yang sistematis" mengimplikasikan bahwa harus ada pendekatan yang terencana dan baik dan proses yang sangat hati-hati untuk melaksanakan audit. Pendekatan ini meliputi “memperoleh dan mengevaluasi bukti secara objektif'.Dua aktivitas yang ada dalam frasa ini adalah auditor harus secara objektif mencari dan mengevaluasi bukti yang andal dan valid. Sementara jenis kualitas dan keandalan bukti bisa jadi akan sangat beragam antara audit, proses dari pengelolahan, dan mengevaluasi merupakan aktivitas yang paling banyak dilakukan pada proses audit. Sebagai analogi kami antara house inspector dan ilustrasi auditing, bukti yang didapatkan oleh auditor harus berkaitan dengan "aserasi tentang kegiatan peristiwa ekonomis" auditor membandingkan bukti yang diproleh atas asresi laporan keuangan manajemen dan tujuan untuk menilai "tingkat kesesuaian" antara asersi tersebut dan krekteria yang telah ditetapkan. Sementara perbedan jenis "krekteria"mungkin tersedia dalam berangam kondisi, prinsip 
akuntansi berlaku umum (generally accepted accounting principles-GAAP) biasanya menjadi dasar bagi asersi manajemen dalam konteks audit atau laporan keuangan.

Inspektorat Pemerintah Daerah dan Peranannya sebagai Audit Internal. Inspektorat Pemerintah Daerah Kabupaten/Kota adalah Aparat Pengawasan Intern Pemerintah Kabupaten/Kota di Indonesia.Tugas Inspektorat Pemerintah Daerah adalah menyelenggarakan kegiatan pengawasan umum pemerintah daerah dan tugas pengauditan.Inspektorat Pemerintah Daerah disebut juga internal auditor pemerintah daerah. Berdasarkan Peraturan Pemerintah (PP) Nomor 60 Tahun 2008 Tentang Sistem Pengendalian Intern Pemerintah (SPIP), peran APIP yang efektif menerapkan paradigma baru. Dalam paradigma baru peran APIP yang efektif diperluas yaitu tidak hanya memberikan keyakinan yang memadai atas ketaatan, kehematan, efisiensi, dan efektivitas pencapaian tujuan penyelenggaraan tugas dan fungsi instansi pemerintah yang di dampingi, namun sampai dengan memberikan konsultansi terhadap manajemen, memberi masukan dan pertimbangan profesional terkait risiko yang dihadapi organisasi.

Kecurangan, definisi fraud menurut Blaks Law Dictionary yang dikutip oleh Karyono (2013:4) adalah "Kecurangan mencakup segala macam yang dapat dipikirkan manusia dan yang diupayakan oleh seseorang untuk mendapatkan keuntungan dari orang lain dengan saran yang salah atau memaksakan kebenaran dan mencakup semua cara yang tak terduga, penuh siasat, licik, tersembunyi dan setiap cara yang tidak jujur yang menyebabkan orang lain tertipu". Prasetyo (2011) menyatakan bahwa fraud atau kecurangan adalah penyakit yang susah untung disembuhkan, maka dari untuk menangani penyakit, lebih baik mencegah dari pada mengobatinya. Para ahli memperkirakan bahwa fraud yang terungkap adalah bagian kecil dari seluruh fraud sebenarnya terjadi. Karena itu upaya utama adalah pada pencegahannya.

\section{Hipotesis.}

$\mathrm{Ha}<$ : internal auditor berperan secara signifikan terhatap pencegahan kecurangan dana desa.

Ho> : Internal auditor tidak berperan secara signifikan terhadap pencegahan pengelolahan dana desa.

\section{METODE PENELITIAN}

Penelitian ini dilakukan di inspektorat di kabupaten Bengkulu Selatan, pada bulan Februari 2020. Jenis penelitian adalah diskritif kuantitatif, berupa data tentang masalah peran internal auditor dalam pencegahan pengelolahan dana desa, data penelitian selama 3 tahun terakhir, yaitu, tahun 2017,2018 dan 2019. Teknik pengumpulan data penelitian menggunakan observasi dan kuesioner. Populasi dalam penelitian ini adalah seluruh Auditor Inspektorat di kabupaten Bengkulu Selatan sebanyak 20 oarang, sedangkan sampel seluruh populasi diambil sebagai sampel dalam penelitianini. Metode analisis data menggunakan statistic dikriptif dengan metode regrensi linier sederhana dan menggunakan alat SPSS.

\section{HASIL DAN PEMBAHASAN}

Populasi dalam penelitian ini adalah seluruh auditor pada Kantor Inspektorat Kabupaten Bengkulu Selatan, sebanyak 20 orang dan di gunakan sebagai Sampel penelitian, Kuesioner yang di bagikan kepada Responden sejumlah 20 tersebut semuanya kembali dan dapat di olah. 
Tabel 1

Rincian Pengiriman dan Pengembalian Kuesioner

\begin{tabular}{|l|l|l|}
\hline \multicolumn{1}{|c|}{ Keterangan } & Jumlah & Persentase \\
\hline Jumlah Kuesioner yang disebarkan & 20 & $100 \%$ \\
\hline Jumlah Kuesioner yang kembali & 20 & $100 \%$ \\
\hline Jumlah Kuesioner yang tidak kembali & - & - \\
\hline Kuesioner yang tidak dapat digunakan & - & - \\
\hline Kuesioner yang dapat digunakan & 20 & $100 \%$ \\
\hline
\end{tabular}

Sumber : Data diolah 2020

\section{Hasil Uji Kualitas Data Hasil Uji Validitas}

Tabel 2

Hasil uji validasi variable peran internal auditor

\begin{tabular}{|l|l|l|l|}
\hline \multicolumn{1}{|c|}{ Item Pertanyaan } & r-hitung & \multicolumn{1}{c|}{ Nilai p } & Keterangan \\
\hline Nomor 1 & 0,736 & 0,000 & Valid \\
\hline Nomor 2 & 0,561 & 0,010 & Valid \\
\hline Nomor 3 & 0,671 & 0,001 & Valid \\
\hline Nomor 4 & 0,792 & 0,000 & Valid \\
\hline Nomor 5 & 0,476 & 0,034 & Valid \\
\hline Nomor 6 & 0,573 & 0,008 & Valid \\
\hline Nomor 7 & 0,783 & 0,000 & Valid \\
\hline Nomor 8 & 0,590 & 0,006 & Valid \\
\hline Nomor 9 & 0,785 & 0,000 & Valid \\
\hline Nomor 10 & 0,553 & 0,011 & Valid \\
\hline Nomor 11 & 0,469 & 0,037 & Valid \\
\hline Nomor 12 & 0,545 & 0,013 & Valid \\
\hline Nomor 13 & 0,648 & 0,002 & Valid \\
\hline Nomor 14 & 0,630 & 0,003 & Valid \\
\hline Nomor 15 & 0,576 & 0,008 & Valid \\
\hline Nomor 16 & 0,511 & 0,021 & Valid \\
\hline Nomor 17 & 0,628 & 0,003 & Valid \\
\hline Nomor 18 & 0,636 & 0,003 & Valid \\
\hline Nomor 19 & 0,563 & 0,010 & Valid \\
\hline Nomor 20 & 0,670 & 0,001 & Valid \\
\hline & & & \\
\hline & & & \\
\hline
\end{tabular}

Tabel 3

Hasil uji validasi variable pencegahan kecurangan

\begin{tabular}{|l|l|l|l|}
\hline \multicolumn{1}{|c|}{ Item Pertanyaan } & \multicolumn{1}{c|}{ r-hitung } & \multicolumn{1}{c|}{ Nilai p } & Keterangan \\
\hline Nomor 21 & 0,484 & 0,031 & Valid \\
\hline Nomor 22 & 0,791 & 0,000 & Valid \\
\hline
\end{tabular}




\begin{tabular}{|l|l|l|l|}
\hline Nomor 23 & 0,764 & 0,000 & Valid \\
\hline Nomor 24 & 0,505 & 0,023 & Valid \\
\hline Nomor 25 & 0,750 & 0,000 & Valid \\
\hline Nomor 26 & 0,491 & 0,028 & Valid \\
\hline Nomor 27 & 0,821 & 0,000 & Valid \\
\hline Nomor 28 & 0,675 & 0,001 & Valid \\
\hline Nomor 29 & 0,580 & 0,007 & Valid \\
\hline Nomor 30 & 0,546 & 0,013 & Valid \\
\hline
\end{tabular}

Berdasarkan uji validitas diatas dapat disimpulkan bahwa semua item yang digunakan untuk mengetahui peran internal auditor terhadap pencegahan kecurangan kecurangan pengelolahan dana desa menunjukkan nilai Pearson Correlation > r tabel sehingga dapat dikatakan semua instrumen valid untuk digunakan.

\section{Hasil Uji Reliabilitas}

Tabel 4

Hasil Uji Reliabilitas

\begin{tabular}{|l|l|l|}
\hline \multicolumn{1}{|c|}{ Variabel } & \multicolumn{1}{c|}{$\begin{array}{c}\text { Cronbach's } \\
\text { alpha }\end{array}$} & \multicolumn{1}{c|}{ Kesimpulan } \\
\hline Peran internal auditor & 0,911 & Reliable \\
\hline Pencegahan kecurangan & 0,834 & Reliable \\
\hline
\end{tabular}

Berdasarkan hasil uji reliabilitas, semua variabel memiliki nilai Cronbach's alpha > 0,7 sehingga dapat dikatakan bahwa setiap variabel dalam penelitian ini telah reliabel dan memiliki keandalan yang tinggi untuk mengetahui peran internal auditor dalam pencegahan kecurangan pengelolahan dana desa.

\section{Hasil Uji Normalitas}

Model regresi yang baik adalah yang memiliki distribusi normal atau mendekati normal. Untuk itu diperlukan uji normalitas, yang dimaksudkan untuk menguji apakah variabel independen dan variabel dependen dalam model regresi mempunyai distribusi normal atau tidak. Pengujian distribusi normal dapat dilakukan dengan uji kolmogorov-Smirnov. Persyaratan data tersebut normal apabila probabilitas diatas 0,05. Hasil uji kolmogorov Smirnov dapat dilihat pada Tabel dibawah ini: 
Tabel 5

One-Sample Kolmogorov-Smirnov Test

\begin{tabular}{|ll|r|r|}
\hline & & $\begin{array}{c}\text { Pencegahan } \\
\text { Kecurangan } \\
\text { Pengelolaan } \\
\text { Dana Desa }\end{array}$ \\
\hline $\mathrm{N}$ & & $\begin{array}{c}\text { Peran Internal } \\
\text { Auditor }\end{array}$ & 20 \\
Normal Parametersa,b & Mean & 85.90 & 43.10 \\
& Std. Deviation & 8.908 & 4.587 \\
Most Extreme & Absolute & .117 & .107 \\
Differences & Positive & .109 & .100 \\
& Negative & -.117 & -.107 \\
Kolmogorov-Smirnov Z & & .521 & .480 \\
Asymp. Sig. (2-tailed) & & .949 & .975 \\
\hline
\end{tabular}
a. Test distribution is Normal.
b. Calculated from data.

Tabel diatas menggambarkan hasil uji normalitas Peran Internal Auditor dan Pencegahan Kecurangan Pengelolaan Dana Desa dengan menggunakan Uji Kolmogorov Smirnov (K-S). Dari tabel tersebut diketahui bahwa nilai p (Sig.) untuk Peran Internal Auditor sebesar 0,949 dan nilai $\mathrm{p}$ (Sig.) untuk Pencegahan Kecurangan Pengelolaan Dana Desa sebesar 0,975. Karena semua nilai p>0,05 maka Data Peran Internal Auditor dan Pencegahan Kecurangan Pengelolaan Dana Desa dikatakan berdistribusi Normal.

\section{Uji Hipotesis}

\section{Uji Regresi Linier Sederhana}

uji t, hasil pengujian hipotesis pertama (H1) yang menyebutkan bahwa peran internal auditor berpengaru secara signifikan terhadap pencegahan kecurangan pengelolahan dana desa dikonfirmasikan pada Tabel 4.12. Tabel 4.12 tersebut menunjukkan bahwa nilai koefisien regresi variabel independensi auditor (X) adalah 0,313 dan nilai t-hitung 3,240. Nilai koefisien regresi ini signifikan pada tingkat signifikansi 0,05dengan $p$ value sebesar 0,005. Sehingga dapat disimpulkan bahwa peran internal auditor berpengaruh signifikan terhadap pencegahan kecurangan dana desa. Sedangkan berdasarkan persamaan regresi terlihat bahwa koefisien variabel independensi adalah positif. Dengan demikian dapat disimpulkan bahwa H1 diterima. Artinya semakin tinggi peran internal auditor secara signifikan dapat meningkatkan pencegahan kecurangan dana desa.

\section{Coefficie nts}

\begin{tabular}{|c|c|c|c|c|c|c|}
\hline \multirow{2}{*}{\multicolumn{2}{|c|}{ Model }} & \multicolumn{2}{|c|}{$\begin{array}{l}\text { Unstandardized } \\
\text { Coefficients }\end{array}$} & \multirow{2}{*}{$\begin{array}{c}\text { Standardized } \\
\text { Coefficients }\end{array}$} & \multirow[b]{2}{*}{$t$} & \multirow[b]{2}{*}{ Sig. } \\
\hline & & B & Std. Error & & & \\
\hline \multirow[t]{2}{*}{1} & (Constant) & 16.256 & 8.328 & & 1.952 & .067 \\
\hline & $\begin{array}{l}\text { Peran Internal } \\
\text { Auditor }\end{array}$ & .313 & .096 & .607 & 3.240 & .005 \\
\hline
\end{tabular}

a. Dependent Variable: Pencegahan Kecurangan Pengelolaan Dana Desa 
Berdasarkan tabel diatas diperoleh persamaan regresi linear sederhana antara Peran Internal Auditor dalam Pencegahan Kecurangan Pengelolaan Dana Desa, yaitu :

$\mathrm{Y}=16,256+0,313 \mathrm{X}$

Dimana :

$\mathrm{Y}=$ Pencegahan Kecurangan Pengelolaan Dana Desa

$\mathrm{X}=$ Peran Internal Auditor

Konstanta regresi sebesar 16,256 menyatakan bahwa ketika tidak ada variabel Peran Internal Auditor maka skor Pencegahan Kecurangan Pengelolaan Dana Desa adalah sebesar 16,256 atau 16 (dibulatkan). Untuk mengetahui pengaruh variable independent (Peran Internal Auditor) terhadap variable dependent (Pencegahan Kecurangan Pengelolaan Dana Desa) dilakukan dengan menggunakan Uji t. Dari tabel diatas diperoleh nilai $\mathrm{t}=3,240$ dengan nilai $\mathrm{p}=0,005$. Karena nilai $\mathrm{p}<0,05$ maka secara statistik dapat dikatakan bahwa ada pengaruh yang signifikan Peran Internal Auditor dalam Pencegahan Kecurangan Pengelolaan Dana Desa.

\section{PEMBAHASAN}

Hasil pengjuian Hepotesis dari satu Variabel" X " dan satu Variabel " Y” yaitu dengan uji t, hasil pengujian hipotesis pertama (H1) yang menyebutkan bahwa peran internal auditor berpengaruh secara signifikan terhadap pencegahan kecurangan pengelolahan dana desa dikonfirmasikan pada Tabel 4.12. Tabel 4.12 tersebut menunjukkan bahwa nilai koefisien regresi variabel independensi auditor (X) adalah 0,313 dan nilai t-hitung 3,240. Nilai koefisien regresi ini signifikan pada tingkat signifikansi 0,05dengan $p$ value sebesar 0,005. menghasilkan satu hipotesis dan dari pengujian terhadap hipotesis tersebut dapat diambil kesimpulan bahwa satu hipotises yang diajukan diterima $(\mathrm{Ha})$ dan satu hipotesis (Ho) ditolak. Pembahasan berikut bertujuan menjelaskan secara empiris hasil penelitian dan analisis pengaruhnya.

Auditor Internal Berperan Secara Singnifikan Terhadap Pencegahan Kecurangan Dana Desa. Berdasarkan hasil pengujian hipotesis dapat di ambil kesimpulan bahwa terdapat pengaruh positif terhadap variabel peran interan auditor, yang berarti semakin tinggi peran interan auditor semakin tinggi pula tingkat pencegahan kecurangan dana desanya. Hal tersebut dapat dibuktikan dari ujiuji yang dilakukan menggunakan program SPSS dan suda di diuraikan diata.

\section{KESIMPULAN}

Dari Pembahasan pada penelitian ini dapat di simpulkan bahwa peran internal auditor berpengaruh secara signifikan terhadap pencegahan kecurangan pengelolahandana desa di Inspektorat kabupaten Bengkulu Selatan, yaitu : Secara Statistik menggunakan Uji t. (t hitung ) diperoleh nilai $\mathrm{t}=3,240$ dengan nilai Signifikan sebesar $(\mathrm{p})=0,005$. Sedangkan tingkat Alpa sebesar $<0,05$.

\section{DAFTAR PUSTAKA}

Atmadja, A. T., \& Saputra, A. K. (2017). Pencegahan Fraud Dalam Pengelolaan Keuangan Desa. Jurnal Ilmiah Akuntansi Dan Bisnis, 1, 7. Https://Doi.Org/10.24843/Jiab.2017.V12.I01.P02

Ghozali, Imam. (2010). Aplikasi Analisis Multivariabel dan SPSS. Badan Penerbit Universitas Diponogoro, Semarang. 
HernadiantoTasin, (2019) Pengauditan. (Suatu Sistem dan Prosedure), Aren Press. Bengkulu. Imam, Ghozali. (2011). Aplikasi Analisis Multivariabel dan SPSS. Badan Penerbit Universitas Diponogoro, Semarang.

Jachi, M. (2019). Dampak Kompetensi Profesional \& Staffing Fungsi Audit Internal Transparansi Dan Akuntabilitas Kasus. 10(8), 149-164.

Noviani, D. P., \& Sambharakreshna, Y. (2014). Pencegahan Kecurangan Dalam Organisasi Pemerintahan. JAFFA Oktober, 02(2), 61-70.

Pramono, S. E. (2003). Transformasi Peran Internal Auditor Dan Pengaruhnya Bagi Organisasi. Media Riset Akuntansi, Auditing, Dan Informasi, 3(2), 181-194.

Priyatono, D. M., \& Udin, A. A. (2019). Pemerintah Daerah Dalam Meningkatkan Opini Audit (Vol. 0025055502).

Indra Bastian, Mediator. (2014). Audit Sektor Publik. Salemaba Empat. Jakarta

Rimbano, D. (2016). Peran Auditor Dalam Pengawasan Keuangan Daerah. Jurnal Adminika, 2(1), $128-136$.

Surat Kementerian Dalam Negeri No. 700/1281/A.1/19.(2016) tentang Pedoman Pengawasan Dana Desa.

Peraturan Menteri Dalam Negeri Nomor 7 Tahun 2008 tentang Pedoman Tata Cara Pengawasan atas Penyelenggaraan Pemerintahan Desa.

Peraturan Menteri Dalam Negeri Nomor 71 Tahun 2015 tentang Kebijakan Pengawasan Di Lingkungan Kementrian Dalam Negeri Dan Penyelenggaraan Pemerintah Daerah Tahun 2016.

Sari, M. E., Arza, F. I., \& Taqwa, S. (2019). Pengaruh Akuntabilitas, Kesesuaian Kompensasi Dan Pengendalian Intern Terhadap Potensi Kecurangan Dana Desa. Jurnal Eksplorasi Akuntansi, 1(3), 1443-1457.

Undang-undangNomor 6 Tahun 2014 TentangDesapasal 112 dan pasal 113.

Undang-undangNomor 6 Tahun 2014 TentangDesa (Lembaran Negara Republik Indonesia Tahun 2014 Nomor 7, TambahanLembaran Negara Republik Indonesia Nomor 5495).

Widyatama Et All. (2017). Pengaruh Kompetensi Dan Sistem Pengendalian Internal Terhadap Akuntabilitas Pemerintah Desa Dalam Mengelola Alokasi Dana Desa ( ADD ). Jurnal Berkala Akuntansi Dan Keuangan Indonesia, 02(02), 1-20.

William F. Massier, Steven M. Glover, dan Douglas F. PRawitt Auditing and Assurance services: a systematic approach $8^{\text {th }}$ ed.yang diterjemakan oleh Denies Priantinah, dan Linda Kusumanining Wadari (2014) Jasa Audit dan Asuransi. Salemba Empat. Jakarta 